\title{
THE IMPLEMENTATION OF ONLINE-BASED LEARNING METHOD IN MADRASAH IBTIDAIYAH NEGERI 2 MATARAM
}

\author{
M. Zaki \\ Universitas Islam Negeri Mataram, NTB, Indonesia \\ muhzakifusa71@gmail.com
}

\begin{abstract}
The massive and colossal migration from face-to-face learning method to the e-learning method due to the Covid-19 pandemic has become a new challenge for all educators in Mataram Islamic State Elementary School 2. The main challenge is to keep students stays active during the pandemic. This article use a qualitative approach with an explorative study, to reveals the problem of e-learning method. This learning method uses the Google Classroom, Zoom Cloud Meeting and WhatsApp Group as a variant of the learning application. In fact, this method has faced various problems; the parents faced some problems like a lack of funds, time and capability to help their children attending the online class. For students, elearning is considered harder than face-to-face learning method. Meanwhile for the teacher, the problems were the lack of skills in using gadget and the difficulty of monitoring and controlling the activeness of students during online class.
\end{abstract}

Keyword: Covid 19 Pandemic, e-learning, Constraints on Teachers; Students; and Parents of Students

\section{INTRODUCTION}

Corona Virus Diseases or known as Covid-19, started at the end of 2019 in Wuhan as its main incubation center, the whole world was affected. The education sector is one of the areas that have been badly affected, schools have not been able to get out of this virus attack. School institutions that from the beginning of their existence orchestrated learning methods through direct, face-to-face, muwajahah, face to face learning, between teachers and students, are no longer a tradition that can be applied. the sound of footsteps and pounding heels of the teachers down the hall in the hallway was no longer heard. The smile and warm greetings of the hero without merit, when starting and ending the lesson are no longer visible. Even the sharp look of suspicion while watching the exam, is now just a memory. All the sadness, jokes, laughter 
that filled the students' days, now began to be quiet. Classrooms become empty with lifeless rows of empty chairs and tables.

Slowly but sure, learning methods by means of direct interaction and faceto-face learning are starting to be replaced by online / online learning systems. This system change was triggered by the policy of closing all schools, as part of the government's efforts to break the chain of spreading Covid-19. UNICEF, WHO and IFRC (2020), said that when the spread going up, schools must be closed temporarily, but the learning process must be carried out through online system learning activities using lots of media. The massive and colossal migration from learning with direct interaction systems to online learning systems, of course, becomes a new challenge for all elements to keep the students stays active despite the schools have closed.

UNESCO has predicted approximately 1.5 billion students and 63 million teachers at the primary and secondary education levels in 191 countries, were affected by the Covid-19 pandemic, something that had never happened before. The education sector then, was "forced" to change the face-to-face learning method to online-based learning. This is the safest way to stop the spread of Covid-19. However, the students right to get a proper education remains become a priority without neglecting health and mental safety.

Based on the d advice from world organizations that concerns in the fields of education and health, The Ministry of Education and Culture issued Circular Number 4 of 2020 concerning Implementation of Education Policies in a Coronavirus Disease (Covid-19) Emergency. There are three policy points related to online system learning. First, online-based learning method provides a learning experience that ends, without being burdened with notes on completing all curriculum achievements for promotion or graduation. Second, it can be focused on life skills education. Third, learning activities and assignments may vary between students, according to their interests and conditions, including considering network access / learning facilities at their home. 
The normative foundation on a national scale is expressed by each region. Through Circular number: 422.3 / 302 / disdik.A / III / 2020, dated March 16, 2020, The Mayor of Mataram, Ahyar Abduh, instructed: First, to all principals of TK / PAUD, SD / MI, and SMP / MTs schools / madrasah. Public and private have to close their learning activities. Second, the learning process during vacation time is carried out by the teacher by giving assignments and tutoring the students through online media. Third, for the time being until normal conditions students is prohibited to do extracurricular activities and gathering using school facilities or outside the school.

The mayor's instruction is the basis law for all schools / madrasahs at the TK / PAUD and basic education levels in Mataram City to close their schools and change the face-to-face learning activities to online learning. Thus, all levels of primary and secondary education, ready or not, must implement the online learning. This online learning activity is a must, Considering the Covid19 pandemic has making time, location, and distance, becomes the biggest problems at this time (Kusuma and Hamidah, 2020). That is why online learning is an alternative solution to overcome the face-to-face learning problems.

Without proper preparation, learning activities through an online system that are carried out suddenly, of course, leaves a bunch of problems. In fact, the education component stutters against it. Hoskins (2013) states it is not easy to do online learning because it must be supported by appropriate classroom design and teaching methods. In addition, network access is the key for optimal online learning. Lembani, et al., (2019) stated that open distance learning increases opportunities for access to wider education source because of the availability of lots of online material. However, this condition is strongly depended by variables such as age, the access to computers and the internet, digital divide, the readiness of school capital and parents of students to access their devices. 
The problems above are also occurred on the practice of online learning at Madrasah Ibtidaiyah Negeri 2 Mataram. At the implementation level, onlinelearning at this institution faces various problems. Starting from the responsibility to prepare the devices and internet access, the lack of competency from several teachers in order to operate the devices, online startup, and application. On the parents side, parents face the problems like the lack of funds and time to accompany their children, and supports the students to participate in online-learning during the isolation. All these obstacles occur and are clearly visible in MIN 2 Mataram City, which is geographically located in the major city, the input row of this school has followed a relatively strict selection stage, and the majority of them come from parents who have middle-high socioeconomic status.

The geographical position of MIN 2 Mataram and the socioeconomic status of the parents of its students should be able to contribute significantly in order to face the online learning in the Covid-19 era. The urgency of this article is to describe the implementation of online learning in the Covid-19 situation at MIN 2 Mataram and to analyze the constraints and the impact on teachers, students and parents. Hopefully, the results of this study can be used as a basis for policy maker for implementing online learning method that suits the profiles of teachers, students and their parents.

\section{THEORETICAL BASIS}

Behind the pain and sorrow caused by Covid-19, there are millions of wisdom in it. One of them is reminiscent of the figure of Heraclitus (544-483 $\mathrm{BC}$ ), a philosopher of change from Greece who is famously known for his popular statement, panta rei ... in this world everything changes but changes itself, everything changes, only one does not change. Nothing remains the same, everything always moves and changes or dies (Sobirin, 2017). Heraclitus' shows how change is a part of human life that cannot be avoided. Anyone will be the part of the change, like it or not, wanted or unwanted. 
Meanwhile, the Chinese philosophy, Zhuangzi, says that we live in a world that is unstoppably change and will continue to change without knowing when the change started and when it will stop. It will be happened everywhere from the past until now. Interestingly, from time to time, the process of change has a different model. In the past, the change process seems to follow a rhythmic tone, a harmonious symphonic tone or calm, predictable, slow but steady. But nowadays, the process of change that occur is like the flood, jazz and rock \& roll music. Changes often happened spontaneously without clear signals, so dynamic, erratic, and tend to be more complicated and lead to chaotic conditions (Wang 2000).

The statements above are the basic instrument in order to understand the Covid-19 effects. In the context of education, the Covid-19 pandemic tends to force all elements of education sector to change the old face-to-face learning method and direct interaction in the classroom between teachers and students, to online-based learning, which previously had almost never been done simultaneously and planned (Sun, Tang and Zou, 2020).

Online learning is defined as a transfer of knowledge using video, audio, images, text communication, and software with internet network support (Zhou \& Zhou, 2020). This theoretical conception assumes online learning as an innovation of learning using website forums and digital technology as part of the 4.0 industrial revolution. The integration of technology integration with various learning material characterize online learning. In addition, and this is the most important, pushing teachers and students to interact and transfer knowledge through digital media. Online is also defined as a computer network that is interconnected with other networks throughout the world (Kitao, 1998). This learning model can facilitate formal and informal training and learning activities, such as facilitating activities and communities of electronic media users, like the internet, CD-ROMs, videos, DVDs, televisions, cellphones, and so on. In this methods, the teachers acts as a facilitator, while 
students take on the role of knowledge constructors, independent learners and problem solvers (Maudiarti, 2018).

There are at least three online learning models identified by Haugey \& Anderson (1998). First, the Web Course, which is learning conducted via web. This model orchestrates online learning as a whole, where communication between students and teachers are constructed by remote systems via web / internet without face-to face. All teaching materials, assignments, consultations, exams, and other learning activities are delivered through the internet. Second, the Web Centric Course, which combines distance learning and face-to-face online learning. In this learning model, the material is partly provided on the web and partly through face to face, as a complement. Third, the Web Enhanced Course, which is enhanced learning through the use of the web / internet. Learning held reciprocally between teacher and students, and learning-process take place on the web / internet.

On the implementation level, online learning can be held using various platforms such as computer-based learning, web-based learning, virtual classrooms, virtual schoology, zoom meeting, websites, social networks and learning management systems. There are lots of media that support online learning such as Google Classroom, Smart class, Zenus, Zoom, Quipper, and Microsoft. The Whatsapp feature includes Whatsapp group which can be used to send text messages, images, videos and files in various formats to all members can be used as an online learning media. Google Classroom allows teachers to develop the students creativity. These various platforms can be used to support the implementation of online learning.

The variety of platforms and resources are available helps support the learning process during the Covid-19 pandemic. Learning activities can be held starting from discussions, presentations to assignments. In tune with the results of the research of Firman and Rahayu (2020) which states that online learning trains student to be independent. It will push the students to involve and improve their observational learning behavior. This behavior can be done 
by reading, interpreting posts, discussing and discussing videos or learning content. This condition will make students get used t0 collect and manage information related to the assignment without limitation of space and time. Online learning allows students to access the information and knowledge from everywhere without limit.

Luthra and Mackenzi (2020) explained how Covid-19 changes the paradigm of all elements of education system. First, the educational process around the world is increasingly interconnected. Second, redefining the role of the educators. Third, focus on a life skills and applicable skills in the future. Fourth, strengthen the role of technology as a part of an education systems proponent. According to Tam and El Azar (2020), The Covid-19 pandemic has triggered three fundamental changes in the world of education. First, change the way how millions of people are educated. Second, Provides new solutions for education that can create innovation. Third, the gap of digital resources creates a wider gap on educational systems around the world.

The assumptions show the Covid-19 is more than able to catalase the educational transformation. The changes have actually started, but it run slowly. In no crisis situations, it is hard to promote the online learning. There are several pre-conditions that must be met. In addition, online learning requires students, who independently classified their goal through the learning process. Due to the Covid-19 pandemic, this transformation becomes indispensable. In a short time, for example, the whole world has changed their conventional face-to-face learning methods in schools into distance learning that relies on technology.

The online-based learning method has weaknesses; the school has a responsibility to assure the availability of adequate internet facilities, It will requires a lot of money and human resources, schools have to ensure that the technical problems will not interfere the learning process. Even though there are lots of problem, online learning has many advantages, including: increasing the interaction between students and teachers, every learning 
activities can be held anytime and anywhere (flexibility of time and place). Increase the potential to reach a global audience, and convenience to updating the learning material content (Waryanto, 2006).

Arnesti \& Hamid (2015) identified the benefits of using online learning, such as improve the students ability to be an independent learners and intensify their interactivity, and memories, providing more experiences with text, audio, video and animation which are all used to transform the information, and makes it easy to deliver, update content, and download. Students can communicate with other through e-mails, forum discussions, chat rooms, and video conferences.

\section{METHOD}

This articles uses a qualitative approach with exploratory case studies. The imposition of this approach and type of research is intended to describe and analyze the implementation of online learning, the types of media and applications and its impact. Data were collected through semi-structured interviews with 18 respondents, each of them: six teachers, students and parents, using purposive sampling. In qualitative research, there is no limit to the number of respondents to make a purposive sample. The most important thing is fulfilling the required data or information (Bernard, 1994).

Interview process ended until data saturation was reached and no new information could be obtained (Guest et al., 2006; Krysik and Finn, 2010). All respondents received a questionnaire before the interview. MIN 2 Mataram as an interview locus for the teachers. Students and their parents stayed at their home. All interviews were signed and with the permission from the respondents, were audio-recorded and then verbally transcribed. For confidentiality purposes, respondents were given the initial name, G refers to the teacher, $\mathrm{S}$ for students and OTS for parents of students. 


\section{Respondents Profile}

\begin{tabular}{|c|c|c|c|c|c|c|c|c|}
\hline \multicolumn{3}{|c|}{ Teacher } & \multicolumn{3}{c|}{ Student } & \multicolumn{3}{c|}{ Parents } \\
\hline Initial & Sex & Age & Initial & Sex & Age & Initial & Sex & Age \\
\hline G1 & Male & 49 & S1 & Male & 7 & OTS1 & Male & 40 \\
\hline G2 & Female & 38 & S2 & Female & 8 & OTS2 & Female & 39 \\
\hline G3 & Female & 46 & S3 & Female & 9 & OTS3 & Female & 48 \\
\hline G4 & Male & 42 & S4 & Male & 10 & OTS4 & Male & 49 \\
\hline G5 & Female & 40 & S5 & Male & 11 & OTS5 & Female & 47 \\
\hline G6 & Male & 45 & S6 & Male & 12 & OTS6 & Female & 47 \\
\hline
\end{tabular}

Analysis and interpretation on this research using thematic data analysis (Creswell, 2013). This is considered to be the most appropriate for any study that aims to explore multiple interpretations. In a thematic analysis, all interpretations are possible (Alhojailan, 2012). A strict thematic approach can produce depth analysis to answer specific questions (Braun and Clarke, 2006, 97). After deep analysis, the researcher can describe the results, according to the main focus of the study.

\section{RESULTS AND DISCUSSION}

Social distancing and physical distancing policies which aims to prevent the spread of Covid-19 encourage all educator members of MIN 2 Mataram to activate classes with a distance online-based learning system. In the current context, this is the most effective mitigation to reduce the spread of the Covid19 outbreak over all teachers, students and other school components. this policy does not mean that all the learning activities have to stopped. learning process were held by implementing the online-based learning method by utilizing various supporting facilities. During the pandemic, all of learning process and evaluation at MIN 2 Mataram used an online system.

The results showed that learning activities carried out at MIN 2 Mataram City since the Covid-19 pandemic, used an online system. According to one respondent, since the Covid-19 pandemic and the closing school policy, learning activities have been carried out using an online system, as a substitute 
for face-to-face learning. Learning with an online system is enforced so that student learning activities can be held like a usual days (G5). A same statement was conveyed by respondent G1, according to him during the Covid-19 pandemic, learning with an online system was the only option for sustaining the learning activities, because face-to-face learning was not possible. Face-toface learning during a pandemic has a potential to endanger all persons, including teachers, students and other school components.

In this situation, place and distance are the biggest problems for all of us. So learning with an online system according to respondent G6 is the best choice, so that all school components are safe from Covid-19 and most importantly students can continue their learning activities even though the school were closed. Another respondent said, to finish all the lessons which were given before the Covid-19, MIN 2 Mataram's teachers passed on the learning activities using the online system until the situation is clearly safe and the school is reopened as before (G4). However, if the situation and conditions get worst, teaching and learning activities using the online system are likely to be continued in the next semester (G3).

The online system is also used to evaluate student learning outcomes. This statement was conveyed by respondent G2. According to him, after teaching and learning activities with the online system finished, according to the academic calendar, the next activity is to evaluate student learning outcomes. In the semester period of the 2019/2020, all semester exams were given by using an online system. We teachers send assignments or questions to students to be answered completed by them at their home as a final semester assignments, then they are collected according to the time limit set by the teacher. The students' final grades listed on the report cards, apart from their ability to do assignments or questions given by the teachers via online, also includes the other components during face-to-face learning activities. The online learning system that we are currently used held to continue the rest of the face-to-face learning that has been going on for eleven weeks effectively. 
This means that online system learning is carried out as much as thirteen weeks effectively from twenty-four weeks effectively in the even semester of $2019 / 2020$.

The statements from the teachers in tune with the statements made by respondents S5 and OTS2. The two respondents confirmed that when the Covid-19 pandemic occurred and schools were temporarily closed, they studied at home using an online system. 'After school was closed due to Covid19 we studied at home. The subject matter and various assignments were sent out by the teacher through Google Classroom. We were also submit our presence through the application, and also all the assignments given by the teacher, we collected through the Google Classroom application (S5). Another respondent stated that according to the schedule, I always accompany my son who is in second grade to participate on his learning activities through the Zoom Cloud Meeting and WhatsApp Group created by the school. These two applications are used interchangeably depends on the situation (OTS2).

Unlike face-to-face learning, Online learning can be carried out only with a set of applications with all the tools that support the learning process. The Google Classroom platform, Zoom Cloud Meeting and WhatsApp Group are sort of platforms that being used in implementing online learning systems at MIN 2 Mataram. One respondent stated that he used Google Classroom. This application is being used for fourth grade students (G4). A similar statement was also conveyed by respondent G5 who taught in fifth grade. In carrying out learning assignments with an online system, the Google Classroom platform is the right choice for fifth grade students, because in terms of age, students can be invited to discuss and solve various problems that exist in the subject matter.

Meanwhile, G1 respondents, teacher in the first grade, and G2 respondents who teach in the second grade, used the Zoom Cloud Meeting platform and WhatsApp Group in carrying out learning with an online system. These two respondents used the platform because for first and second grade students, 
they still needed the presence of the teacher directly in learning activities even though through a webcam. In contrast to the teachers in a higher classes $(4,5$ and 6), in terms of age, students are more mature and more realistic in understanding the teaching material that is delivered even without the direct presence of the teacher. 'While we teach in small classes (1, 2 and 3), without the presence of the teacher directly, we can be sure that the material $p$ is relatively difficult to understand. That is why; we chose to use the Zoom Cloud Meeting and WhatsApp Group platforms (G1). The same statement was conveyed by respondent G2, that in terms of age, second grade students really need the direct presence of the teacher in their learning activities to help and guide them in order to understand the lessons. Zoom Cloud Meeting Platform can bring together teachers and students in face-to-face learning. With the WhatsApp platform, teachers can send their teaching materials, power points and videos.

Online-based learning with multiple platforms, on the evel of implementation encountered various problems. The data shows that the various platforms used in online learning at MIN 2 Mataram are all internetbased. It is true that these various platforms can be downloaded for free, but in order to be used there must be an good internet network, and this requires a relatively large amount of money. OTS3 respondents stated that online learning is quite burdensome from an economic perspective, beside from meeting the daily needs which are quite a lot, I also have to buy an internet data so that my son can participate in online learning. On the other hand, the sources of income have decreased due to the sluggish economy during this pandemic. We hope that there is a solution from the government or schools in the form of subsidized internet data so that online learning can run and the costs that must be allocated to buy the data can be transferred to meet other basic needs.

The same statement was conveyed by the respondent's parents from fifth grade students, with a high tone and emotional facial expressions expressed 
their opinion, that online learning is hard for our family. Imagine, online learning requires a device (laptop or mobile phone). To buy this device is certainly very difficult for us, who have three children whose already at school age. After the Covid-19 pandemic, I experienced layoffs (layoffs), and until now I still work freelance because there is no permanent job. To meet basic needs alone is very difficult especially the costs that must be provided to support online learning. The government should immediately open a school so that the children can go to school and study with their teachers. There is no longer any reason to close schools because public areas such as markets, malls, places of worship and others have been opened (OTS5).

Beside the economic constraints, the limited time for parents to accompany their children during online learning is also the biggest problem. One respondent stated that online learning implemented by schools during the Covid-19 pandemic was indeed burdensome and worrying. 'On the one hand, I had to go to work, on the other hand, at the same time, my son who was still in the first grade had to take online learning. It's really burdensome, because my wife and son are not yet proficient in using the technology used by the school in this online learning. In the office I didn't focus on work because I was worried about my son that he would not be able to follow the lesson. Meanwhile, the agency where I work (private sector) does not allow their employee to work from home like government agencies. There must be a wise solution from schools, especially for first graders who do not understand much of the technology. Besides that, the majority of first grade students cannot read and write, including my son (OTS1).

A similar statement was made by OTS2 respondents, who did not have enough time to accompany their daughter who is in the third grade in online learning. Online learning carried out by schools is simalakama for us. Imagine, We have to accompany them when studying online, but at the same time, my wife and I both work. Assisting children to study every day at home, of course, will make our jobs ineffectively done. On the contrary, if we focus on our jobs 
we would be worrying about our children that they will not finish the lessons. It's really confusing, because after coming home from work late in the evening, my daughter often complains in tears because she doesn't understand the subject by her teacher. This situation makes us in a hopeless state my daughter is getting stressed not being able to complete the assignments given by the teachers. As parents, we really hope that there are solutions provided by the school so that everything can run well. This means that we as parents can focus on working to meet our daily needs, while children can focus on learning without being accompanied by their parents.

Another problems is the inability to understand the subject matter when their children need help or guidance to complete the assignments given by the teachers. One respondent stated that when his son, who is in the sixth grade, asked for help in completing assignments in Mathematics, he seemed helpless because he did not have good enough competency on that subject (OTS6). Likewise with other respondents who stated that they were unable to help their daughter while completing assignments in Arabic because they did not have any knowledge that would be helpful. That is why I hope the school will reopen soon so that children can study with their teachers (OTS4).

The other problems experienced by the students were the difficulty to understand the subject and assignments given by the teachers. Respondent S5 who sat in grade five stated that the material provided by the teacher was quite limited, it was only short discussion without being completed by an explanation as in face-to-face learning in class. Therefore, when working on the assignment, it was relatively difficult. A similar statement was also made by S2 respondents who were in second grade. For him it was difficult to learn through the online system, the teacher only sent material without being given an explanation. In addition, both parents do not have time to accompany them because they have to go to work.

Another problem faced by students is the limited hardware devices for online learning. Respondent S4 stated that in order to take part in online 
learning, 'I had to use it alternately with my siblings. We only have one laptop, therefore we have to use it alternately. The problem comes when we have to use it on the same time. This situation made us both left behind. Meanwhile, S3 respondents stated that studying at home with an online system is boring because you are always learning alone without friends and teachers accompanying you as face-to-face learning in class.

Teachers also experience various problems in online learning. The obstacle experienced by teachers is the limited skills in using technological devices. The G5 states that online learning using various platforms established by the school is difficult because these technological devices have never been used at all in previous times. In general, face-to-face learning does not require technological devices such as online learning, therefore there must be some training before use it first so that learning can run well. Meanwhile, respondent G2 experienced problems in supervising and controlling students when online learning. Students cannot actively participate in online learning which is carried out on a predetermined schedule. The other problem is the activeness of students to collect their assignments. they had always collect assignments out of time limit.

The research data that was collected referring to the focus; The implementation of online-based learning in MIN 2 Mataram during the Covid19 period, the media/applications that have been used and their impact to all persons; parents, students and teachers. Based on these data, researchers try to analyze them. The analysis of the data was not carried out in a detailed, rigorous and alphabetical manner, but focused on the most crucial and prominent data.

The data result on the implementation of learning during the Covid-19 period at MIN 2 Mataram shows that learning activities are carried out with an online system. This system was implemented simultaneously, hastily and without through preparation. Teachers, students and other components of education are required to undertake unprecedented and colossal practice of 
that have never done before, from face-to-face and conventional learning to online-based learning or distance learning method. Indeed, the implementation of an online learning system is not limited to the current era of the industrial revolution 4.0. Under normal conditions, online learning can be effectively done even though teachers and students are in different places. This system is also able to solve student problems to gain knowledge during the Covid-19 pandemic. That is why, currently all education components in MIN 2 Mataram are urged to make innovations and adaptations related to the use of technology to support the online learning process so that it can run effectively.

In the era of technology, teachers and students are required to have abilities to use modern technology. With the work from home policy, it is force them to accelerate and mastering all the digital learning technology as a necessity for them. The demands of this need make all components in MIN 2 Mataram choose and implement various online media such as Google Calssroom, Zoom Cloud Meeting and WhatssApp Group to support online learning, as a substitute for face-to-face learning, without reducing the quality of learning materials and the learnig goals.

MIN 2 Mataram use Google Classroom to support online based learning, apart from the fact that this application service is free, Google Classroom allows teaching and learning activities to be more productive and meaningful by simplifying assignments, increasing the discussion, and fostering communication between users. Teachers can create classes, give assignments, send feedback and see everything in one place. The Google Classroom platform is easy to use. The teacher can prepare the class and invite students. On the class assignment page feature, teachers and students can share information, teaching materials and ask questions. With Google Classroom, teachers can save more time, paper and other materials. They can create classes, give assignments, communicate and manage, all in one place. Google Classroom also offers better interface. Students can view work on the classwork page 
feature, stream, or on the class calendar. All class materials are automatically stored in the Google Drive folder.

In addition to the various features available, Google Classroom allows for more effective communication between teachers and students or between students. Teachers can create assignments, post announcements, and start live class discussions. Students can share material with each other and interact in the classroom stream or through email. Teachers can also quickly see who has and hasn't completed assignments, and provide real-time grades and feedback. Last but not least, Google Classroom is relatively affordable, safe, available to schools, contains no ads and did not use student data for advertising purposes.

MIN 2 Mataram City also use Zoom Cloud Meeting platform to carry out online learning, considering that this application or software has various advantages, including being used for long-distance communication media with features in the form of video conferencing, online meetings, and chat. This software allows teachers and students to hold meetings without having to be in the same room with many people. Zoom Cloud Meeting is a virtual meeting application that can accommodate many participants in one conference session. Like most meetings, virtual meetings usually have a large number of participants. The Zoom Cloud Meeting application is claimed to be able to accommodate up to 1,000 participants and 10,000 viewers in a group or live video room. Herein lays the relevance of using this application in online learning activities at MIN 2 Mataram. This application can accommodate all students in one particular class when online learning is carried out by each teacher.

One of the advantages of Zoom Cloud Meeting is that it is able to present HD video quality and clear voice so that it will be easier when communicating. In addition, an pros of the Zoom Cloud Meeting application is that it provides various interesting features. For example, it can record and save videos during the meeting, Clear facial skin color, change the background as desired, and schedule online meetings. In the Zoom Cloud Meeting application, teachers and 
students can give treatment to the material that is delivered or discussed (for example: giving bold or underline to scribble on the material) with the intention of deepening understanding of the material presented. In addition, Zoom Cloud Meeting application can be run on various devices including Android phones, IPhones, PCs, or Laptops.

These various applications, software or platforms can be used frequently, as a medium in carrying out online-based learning. By using this online media, students and teachers at MIN 2 Mataram City have indirectly mastered the ability to use and access technology. The teacher is being pushed to be able to master various online learning tools, and it will create more varied learning methods and models that have never been done before. For example, the teacher makes creative video content as learning material. In this case, the teacher is being more persuasive because it makes students more interested in the material provided by the teacher through the creative video. On the other hand, students will certainly be able to understand what is explained by the teacher through the creative video. So, students do not feel bored in taking online learning. The use of technology in giving assignments for students can also lead to creativity among students in developing the basic knowledge they already have. With a variety of learning methods from the teacher, they can create a innovative learning product that can develop their creativity, without leaving the subject matter that has been delivered by the teacher.

Behind the various advantages and conveniences, as well as the diversity of technological devices, online learning can be an ideal choice in various situations and conditions, especially in the conditions of the Covid-19 pandemic. This can be carried out effectively and efficiently if it is preceded by careful planning and through preparation. Before implementing online learning, all educational components (teachers, students and parents) must have competency, knowledge, skills and tools to access the system. It also need the readiness of the government and other stakeholders in preparing the 
infrastructure, in order to minimize the obstacles and problems that occur, as found by researchers at MIN 2 Mataram.

Based on the results of the study, the problems of online learning found in MIN 2 Mataram include: limited costs for accessing the internet, limited time for parents to accompany their children when participating in online learning and the inability of parents to understand subject matter when their children need guidance. Meanwhile, the problems experienced by the students were that most of them felt that online learning activities were much more difficult than face-to-face learning, as well as the limitations of supporting devices such as Android cellphones and laptops. Meanwhile, the problems experienced by teachers were the limited skills in using information and communication technology. Another problems experienced by teachers is the difficulty of guiding and controlling students during online learning.

The implementation of online learning is dependent on various factors; First, the readiness of the government to provide a fast and wide internet connection, subsidized internet data, digital device assistance, and increased digital capacity to minimize inequality in access experienced by the education component. There must be a specific budget allocation to support the smooth running of these online learning activities. This learning cannot be done if neither the school nor the parents have sufficient funds to access the internet. Online learning will not happen smoothly when teachers and students both do not have computers, cellphones, or internet data and internet networks. Especially for students who have limited access, the government must have concrete solutions, especially for all students from poor families. The will be increasingly marginalized because they do not get their rights to get proper education. Luckily, the government recently allowed the BOS (school operational assistance) fund to support the implementation of online learning. The government also collaborates with TVRI to present educational programs through television. 
Second, school ability depends on their financial ability, such as infrastructure that supports the online learning, including: internet connection, internet data's, laptops, and ability to use technology. The socioeconomic background of students also decides whether distance learning activities can be optimally carried out or not. Public schools in urban areas or private schools that have students who come from upper middle socioeconomic classes will have no difficulty in carrying out online learning. There are no problems related to access to the internet and technological devices. Inversely proportional to state schools in rural areas or private schools whose input comes from poor families.

Third, teacher creativity in creating online learning material for students also plays an important role. Teachers have a duty ensure that learning is fun, full of meaning, awakens creativity, critical power, and is able to make students independent. In pandemic situations, teachers cannot directly face their students. The creativity of the teacher will lead to lure students to continue their enthusiasm for learning. If you only give students the usual assignment, it will certainly make them bored. This is the importance of improving teacher skills in accessing and utilizing various technology tools. Because not all of them are familiar with the technology. The older the age, the greater the barriers to technology use. Teachers over 45 years of age experienced a relatively greater barrier.

Fourth, Parents participation is very important for the success of online learning. A dilemma situation happens when parents cannot attend to accompany their children because they still have to work. These are people from working class that do not have the luxury of working from home. While they do not have other people who can help accompany their children. Parents who have the opportunity to work from home but still prioritize office work are also unable to help their children learn optimally. Especially for children at an early age, this is of course a problem. If both parents work and they do not have a household assistant, for example, they should be able to divide the roles 
of caring for the child. If this cannot be addressed wisely, it will lead tomental health issues again that should be anticipated.

Online-based learning method has opened up various educational problems in this country. It shows us that education development in Indonesia needs support from various sectors. Education system as a complete ecosystem cannot be separated from political policies, technology support capacity, good infrastructure, and support from parents / community. Without all of these, education cannot be optimized in order to build our better future. Wallahu a'lam bishawab.

\section{CONCLUSION}

The Covid-19 pandemic initiated various educational elements at MIN 2 Mataram to implement an online learning system. With various models of the platform that have been used, generally speaking, online learning is able to solve the students problem in order to learn even though the teacher and students are in different places. This system also makes teachers and students beings pushed to make innovations related to the use technology to support online-based learning so that it can run effectively.

There are various constraints at the level of implementation, however, these constraints only happened because this system is implemented simultaneously, hastily and without through preparation. To optimize the results, good and sustainable infrastructure is needed; strengthening the skills an competency to use technological devices, We need good policies from stakeholders to facilitate and extend the access to educational components in order to held the online learning system.

\section{REFERENCES}

Alhojailan, M. (2012). Identification of learners' attitudes regarding the implementation of read/write web, blog tools: a case study in higher 
education. 7th Disco conference reader: New media and education. In: Prague: Centre for Higher Education Studies, pp. 58-73.

Arnesti, N., \& Hamid, A. (2015). Penggunaan Media Pembelajaran OnlineOffline Dan Komunikasi Interpersonal Terhadap Hasil Belajar Bahasa Inggris. Jurnal Teknologi Informasi \& Komunikasi Dalam Pendidikan, 2(1).

Bernard, H.R. (2002), Research Methods in Anthropology: Qualitative and Quantitative Methods, 3rd ed., Altamira Press, Walnut Creek, CA.

Braun, V. and Clarke, V. 2006. Using thematic analysis in psychology. Qualitative research in psychology 3(2), pp. 77-101.

Creswell, J.W. (2013), Qualitative Inquiry and Research Design: Choosing among Five Approaches, 3rd ed., Sage, Thousand Oaks, CA.

Firman, \& Rahayu, S. (2020). Pembelajaran Online di Tengah Pandemi Covid19. Indonesian Journal of Educational Science (IJES), 2 (2), 81-89.

Guest, G., Bunce, A. and Johnson, L. (2006), "How many interviews are enough? An experiment with data saturation and variability", Field Methods, Vol. 18 No. 1, pp. 59- 82. [10]

Haughey, M. dan Anderson, T. (1998). Networking Learning: The Pedagogy of the Internet. Montreal: Cheneliere/ McGraw-Hill

Hoskins. Barbara J. (2013). Is Distance Learning Transformational?. The Journal of Continuing Higher Education, 61:1, 62-63 DOI: 10.1080/ 07377363.2013 .759488$.

Kementerian Pendidikan dan Kebudayaan. (2020). Surat Edaran Kemdikbud No 4 Tahun 2020 tentang Pelaksanaan Kebijakan Pendidikan Dalam Masa Darurat Coronavirus Disease (Covid-19). Jakarta: Kemendikbud. (Online) (https://www.kemdikbud.go.id/main/blog/2020/03/mendikbudterbit -kan-se-tentang-pelaksanaan-pendidikan-dalam-masa-daruratcovid19), diakses 25 April 2020. 
Kitao, Kenji and Kitao, S. Kathleen. (1997). Selecting and Developening Teaching/LearningMaterials. The Internet TESL Journal for Teachers of English as a Second Language. Vol. IV, No. 4.

Krysik, J.L. and Finn, J. (2010), Research for Effective Social Work Practice, 2nd ed., Routledge, New York, NY.

Kumparan.com. (15 April 2020). Bagaimana Pembelajaran Jarak Jauh di Indonesia Selama Covid-19, h. 1

Kusuma, J. W., \& Hamidah. (2020). Platform Whatsapp Group Dan Webinar Zoom Dalam Pembelajaran Jarak Jauh Pada Masa Pandemik Covid 19. Jurnal Ilmiah Pendidikan Matematika Volume, 5 (1).

Lembani, Reuben, dkk. (2020). The Same Course, Different Access: The Digital Divide Between Urban and Rural Distance Education Students in South Africa.Journal of Geography in Higher Education, 44:1,70-84,DOI: 10.1080/03098265.2019. 194876.

Luthra, Poornima \& Mackenzie, Sandy. 2020. 4 Ways Covid-19 Education FutureGenerations. (Online), (https://www.weforum.org/agenda/2020 /03/4-ways-covid-19-education-future-generations/), diakses 24 April 2020.

Maudiarti, Santi. (2018). Penerapan E-Learning di Perguruan Tinggi. Perspektif Ilmu Pendidikan, 32 (1), 53-68.

Sobirin, Achmad. (2017). Budaya Organisasi Pengertian, Makna dan Aplikasinya Dalam Kehidupan Organisasi. Yogyakarta : IBPP STIM YKPN.

Sun, L., Tang, Y., \& Zuo, W. (2020). Coronavirus pushes education online. Nature Materials, 20200205. (Online), (https://doi.org/10.1038/s4 15 63-020-0678-8) diakses 2 April 2020.

Tam, Gloria \& El-Azar, Diana. (2020). 3 Ways The Coronavirus Pandemic Could Reshape Education, (Online): (https://www.weforum.org/agenda/ 2020/ 03/3-ways-corona-virus-is-reshaping-education-and-what-changesmight-be-here-to-stay/07), diakses 21 April 2020 
UNICEF, WHO \& IRC. (2020). Key Messages and Actions for Covid-19 Prevention and Control in Schools, (Online): (https://www.who.int/docs/defaultsource/corona-viruse/key-messages-and-actions-for-covid-19-prevent ion-control-in-schools), diakses 3 April 2020.

Wang, Y. (2000). Philospohy of Change and the Deconstruction of Self in the Zhuangzi, Journal of Chinese Philosophy, 27:3, pp. 345 - 360.

Waryanto, N. H. (2006). On-line Learning Sebagai Salah Satu Inovasi Pembelajaran In Pythagoras. (Online), (http://staff.uny.ac.id/ sites/default/files/132304807/) Online Learning sebagai Salah Satu Inovasi Pembelajaran. (Vol. 2, Issue 1, 10-23).

Zhou, L., \& Zhou, M. (2020). School's Out, But Class's On, The Largest Online Education in the World Today: Taking China's Practical Exploration During The COVID-19 Epidemic Prevention and Control as An Example. The Largest Online Education in the World Today, 4 (2), 501-519. 